Metodički obzori 6(2011)3

Professional article

UDK: 37-053.5:81'246.2/.3

Received: 23. 11. 2010.

\title{
BILINGUAL EDUCATION
}

\author{
Andrea Močinić, BA \\ Primary school teacher Buie (Croatia) \\ e-mail: amocinic@gmail.com
}

\begin{abstract}
Bilingualism; the ability of understanding and speaking two languages, is a very interesting but complex topic. Consequently, speaking of bilingual education means finding various pedagogical theories and methodologies for practical usage. In this article there can be found a few studies made by some well known researchers in pedagogy, psychology, linguistics (Baker, 2007; Bialystock, 2006; Titone, 1993; Deshays, 2003) and a confrontation between their different ideas. The article is based most of all on the types of bilingual education, confronting them with each other, finding their deficiencies and their values, and finally finding the best among those typologies. Conclusively, the authors try to find out the most suitable type of bilingual education for the istrian territory, which has been bilingual for centuries. School

Key words: Bilingualism, Multiculturalism, Interculturalism, Education,
\end{abstract}

\section{Introduction}

In the Garzanti dictionary of Italian language (1965) the definition of bilingualism is: «the ability of an individual or a community to use two languages naturally», whereas for a bilingual person it is written: «a person that speaks or uses correctly two languages». However, things are not that simple. According to some authors (Titone, 1993; Deshays, 2003; Bialystok, 2006; Baker, 2007), it is impossible to find one definition that can satisfy all the various combinations of languages, nationalities, grammar rules, political and cultural environment, and all other variables that make bilingualism such a complex and delicate field. For example, Bialystock (2006) describes a bilingual person as the one who speaks equally two languages, who also acts appropriately in a sociocultural way in both languages. On the other hand, Titone (1993) suggests that bilingualism is in the ability to speak a second language using structures and concepts distinctive to that language, instead of paraphrasing from the native language. These examples show how difficult it is to define bilingualism in order to satisfy both linguistic and social aspects. 


\section{Cognitive theories on bilingualism}

For a better analysis of the topic it is important to be acquainted with various theories acquainted with cognitive functioning and bilingualism, or at least the major ones. The first theorists reported negative conclusions about that relationship, and Cummins (1980; in Baker, 2007) gathered them into Separate Underlying Proficiency Model of Bilingualism. In the first half of the 20th century, researchers believed that two languages could not coexist in a person's mind at the same level, and that those two languages operated separately without transfer. It was believed that a second language took second place to the first one, hence diminuishing its level of proficiency. Later, new researches found out that there exists equilibrium between the two languages, and that, consequently, there appears to be enough cerebral living quarters for them both. Cummins (1980, 1981; in Baker, 2007) again names this period as the Common Underlying Proficiency Model of Bilingualism. One of the most interesting theories about the relation between cognitive functioning and bilingualism is the Thresholds Theory, first postulated by Skutnabb-Kangas (1977; in Baker, 2007) and Cummins (1977; in Baker, 2007). The first threshold is a level that a child has to reach to avoid negative consequences of bilingualism. The second threshold is a level that permits a child to experience positive benefits of bilingualism. A problem with this theory is the necessity of defining precisely the level of language proficiency a child must attain in order to avoid negative effects of bilingualism, and to attain its positive advantages. Cummins (1978, 2000; in Baker, 2007) also postulated the Developmental Interindipendence hypothesis. It suggests that a child's second language competence is partly dependent on the level of competence already achieved in the first language. The more developed the first language, the easier it will be to develop the second language, whereas if the first language is at a low stage of evolution, it will be more difficult to achieve a high level of bilingualism.

\section{Types of bilingual education}

To be able to do the analysis of bilingualism from a pedagogical point of view, we need to name the types of bilingual education first. Appropriate education is important to becoming an efficient bilingual, but first a person needs to be able to infiltrate and to camouflage in the society of two or more languages, without being seen as a stranger. It is a tough and long lasting achievement, which needs a lot of well canalized work, done by the school and the parents, but also by the individual's society.

There can be various types of bilingual education: they depend on how the two languages are taught, on the teaching motives and on the teachers, but also on the pupils, methods, state policy and society's attitude towards bilingualism. The factors influencing bilingual education are multiple and various, and therefore a good classification is needed to get a global idea of the topic.

First of all the term bilingual education is used quite differently throughout the countries. For example, as reported by Brisk (1998; in Bialystock, 2006), in the USA the term is used to describe non native English children's education, while elswhere it is used to describe an education in two languages, like it is in most parts of Europe. 
One of the first detailed classifications of bilingual education was given by Mackey (1970; in Baker, 2007), who described 90 different models of bilingual schools, and considered as variables, the pupil's mother tongue, the language of the school curriculum, the languages of the school's community and the social condition of those languages in that region and in the world.

Another type of classification of different kinds of bilingual education is considering the goals of that education. The division that follows is very interesting and useful, it partly clarifies the ideas, but at the same time it is just a static explanation of a constantly evolving concept. Baker (2007) gathers various types of bilingual education in ten different categories, which are divided in three major groups, depending on the linguistic goals of each type of bilingual education.

\section{Monolingual forms of education for bilinguals}

The first type of program is called Mainstreaming/Submersion Education. This is the assimilation of minority language pupils within the major schools, who are taught throughout the curriculum in the language of the majority, without paying attention to their mother tongue. In the United States, a similar system is used in Structured immersion programmes, which include only minority language children, and where learning the language is easier, because the initial level of knowledge is more or less the same for everybody. This type of program is typical of colonial powers and a policy discriminating immigrants, it is harmful and unfair towards minority children, and thus leads them to frustration, disinterest, hence impoverishes them educationally, politically and economically, as indicated by Carrasquillo and Rodriguez (2002; in Baker, 2007), and Skutnabb and Kangas (1981, 2000; in Baker, 2007).

The second program is called Mainstreaming With Pull-out Classes. This type of education consists in withdrawing minority language children from mainstream classes for compensatory lessons in the majority language. Although this program is definitely more suited to the minority students, who can learn the language better, interact more during school hours, and work more spontaneusly and freely, it is still seen as negative by the authors. For example Ovando (2003; in Baker, 2007), points out that withdrawn children may fall behind on curriculum content, there may also be hostility with their majority peers, which leads to stereotypes and labeling, disagreement and division into two groups.

The third program is called Segregationist Education. It occurs where minority language speakers and majority language speakers are completely divided: to minority children the access to majority schools is denied, they attend different schools where the program is taught in their own language. Such policy is discriminatory and separatist, and can be imposed through law or practice. In this way the minority group is maintained via subservience and segregation.

\section{Weak forms of bilingual education for bilinguals}

The first program of this group is called Transitional Bilingual Education. This program consists in teaching minority children in their language until they are thought to 
be proficient enough in the majority language to cope with it in mainstream education. The aim of this program is still that of assimilation, it just slows down the submersion, by constantly increasing the classroom use of the majority language and consequently decreasing the use of the mother tongue. Transitional bilingual education can be split into two major types: early exit and late exit. The first one refers to two years help using mother tongue, while the second one allows around $40 \%$ of classroom teaching in the mother tongue until the 6th grade. The teachers working in such classes need to be bilingual. Often such bilingual teachers can be assistants, to help those in need to cope with the existing language barriers.

The second program of this group is called Mainstream Education with Foreign Language Teaching. It is about foreign language lessons as a subject in the curriculum. Very often the chosen foreign language is one of the world mainstream languages, e. g. English, Spanish, German, French, Italian, etc., taking, however, into account the most useful in a certain region. Thus, for example, here in Croatia, but also in the most parts of Europe and the rest of the world, the first foreign language taught is English, for the simple reason that it is spoken and used in all major institutions (European Parliament, European Court, United Nations, etc.) and in most Internet sites, which is the most important medium at the moment. In this way the next generations are being prepared to an increasingly multicultural and multilingual future. The problem with this type of program is that it rarely produces functional bilinguals, able to communicate in a second language with a native speaker. The exception that proves the rule are the Scandinavian regions, where there is a high degree of efficiency in the second language, which is mainly due to a high motivation level.

The last program of this group is called Separatist Education. It is about a type of education also called secessionist by Schermerhorn (1970; in Baker, 2007), because a minority language tends to detach itself from the majority language. In fact, the objectives of these schools are monolingual and monocultural, trying to maintain independence from the majority language and culture. Various reasons can determine such a choice: political, religious, even the survival of a culture, or others as well.

\section{Strong forms of bilingual education for bilinguals}

These are the types of true bilingual education, and the first program is known as Dual Language Bilingual Education. It is also called two way, and occurs when approximately equal number of minority and majority language students are in the same classroom and both languages are used during the lessons. The aim is to produce relatively balanced bilinguals, which means efficient in both languages. The two languages are to be used in a balanced way in the classroom (alternate use of two languages weekly, daily, in subjects, etc.), so that neither becomes dominant. The dominance of either of the two languages would lead to divisions among pupils, group formation, exclusion and negative competition. The number of pupils from the majority and the minority groups should be more or less equal, and if it is not possible, it is recommended a larger number of minority students, for the simple fact that this will keep the prevalence of the minority language in schools, as in the surrounding environment (political, economic, cultural) supersedes the language of the majority. Such a scheme has to start from a dual language kindergarten, continuing through a 
similar primary and secondary school; it can exist in a structure on its own or coexist in the building of a majority school. Educators, teachers, professors, psychologists, directors, and the rest of the staff should be bilingual. In the absence of bilingual teachers, there can also work two teachers, one for each language. The central idea of this type of education is language separation, which means there should not be mixing of the two languages. The mission of all dual language bilingual schools is to produce bilingual, biliterate and multicultural children.

The second type is called Heritage Language Bilingual Education. It occurs when minority children are taught in their native or heritage language, and the objective is achieving complete bilingualism. Baker (2007) states that in the US this form of bilingual education is sometimes called maintenance bilingual education or developmental maintenance bilingual education, but such a program can be found all over the world (Australia, Spain, New Zealand, ecc.). The language mainly used is the minority language, but sometimes the majority language is used, too, in percentages for a number of subjects selected by the school board or defined by the school policy. The language of the majority is used for the rest of the time outside the school, and that is why the pupils are encouraged to use the language of the minority during most lessons. Schools with similar educational programs are often supported by foreign governments or religious institutions.

The third type of program is called Immersion Bilingual Education. It consists in teaching the curriculum in a second language, with the aim of producing efficient bilinguals. This type of bilingual education derives from a Canadian educational experiment in the 1960s. A few English speaking, middle-class parents persuaded school district administrators to set up an experimental kindergarten class, in which the children would have become bilingual and bicultural. Since then (Baker, 2007), this type of education has spread rapidly in the rest of Canada and in parts of Europe (Spain, Finland, Scotland, Ireland, Switzerland, etc.), and also in other parts of the world (Japan, Australia, Colombia, South Africa, etc.). There are various types of immersion bilingual education, and they differ according to the age at which the child starts the experience (early immersion - from the kindergarten, middle immersion - at about nine years old, and late immersion - after ten years old) and the amount of time spent in immersion (total immersion and partial immersion). Early Total Immersion has been the most popular program in Canada.

The last type of program is called Bilingual Education in Majority Languages. The Majority here would be for world spread languages like English, German, French, and so on. This type of education comprises the joint use of two majority languages in a school. Such schools are in society where the majority of the population is already bilingual or multilingual (e.g. Singapore, Luxembourg) or where there is a significant number of people of different nationalities who want to become bilingual (e.g. English or Americans living in Japan). The two main examples of this type of education are International Schools (spread all over the world, they teach English and another majority language, school fees are paid and the teachers come from various parts of the world) and the European Schools Movement (students come from different European nations, they are taught in two or more different languages, his or her native language and other EC languages, aiming to produce true European citizens). 
Unlike Baker's (2007) ideas, Brisk (1998; in Bialystok, 2006) distinguishes two main types of bilingual education programs. The first one is called Bilingual Education Models, which requires the usage of two languages, and tries to produce efficient bilinguals. It includes: dual language schools (e.g. international schools, such the United Nations School in New York City), Canadian immersion education, two-way bilingual education (which includes minority-language and English-speaking children), two-way bilingual immersion, maintenance bilingual education, transitional bilingual education, submersion with native language support, bilingual immersion education, and integrated bilingual education.

The second type is called Monolingual Instruction Models, in which little or no attention is paid to children's native language. This model includes English as a second language programs and structured immersion (sheltered native language).

\section{Conclusion}

To summarise, we can see that the main problem is the complexity of the topic. Despite trying to collect various factors that interact with each other and group them, obtaining a number of objective patterns for the collection of various types of bilingual education, it is still too complicated for a single classification. However, Bakers (2007) and Brisks (1998; in Bialystok, 2006) classifications are well-structured, valid models.

Taking into account the types of bilingual education listed by Baker (2007), we can conclude that the group with robust forms of bilingual education for bilinguals contains the best methods to educate bilingualism.

For example, the monolingual forms of education for bilinguals contain teaching methods whose only purpose is to teach immigrants the language of their new home, without considering their mother tongue and/or their culture of origin. Such methods do not produce equilinguals, (persons who speak equally fluently both languages) and often they are the cause of frustration, disappointment, insecurity and even hatred towards one of the two languages, usually the majority language, as it was acquired by force.

Weak forms of bilingual education for bilinguals do not produce equilinguals either. These methods are better than the first ones, but they still represent immigrants' assimilation into the language and culture of the majority. In some cases, like in the method called Mainstream education with foreign language teaching, the goal is not assimilation, nevertheless it is still the wrong method for the majority of students. Only children that are good in learning languages, or those with parents or relatives that speak that language, will take benefits from a few weekly lessons provided by the plan and curriculum. This type of education, as said before, is used in Croatia and in the rest of Europe in state schools.

As mentioned before, Baker (2007) states that the strong forms of bilingual education for bilinguals have the best methodologies for an equilingual education. These are methods by which appropriate attention is given to both languages and culture, by which diversity is seen in an entirely positive way, and which brings respect, friendship, serenity and harmony in the classroom. According to Baker (2007) such educational 
methods are used mostly in bilingual countries (e.g. Canada, Luxembourg, Indonesia, etc.) or countries with a highly developed social culture (Nordic countries, Japan, etc.).

Croatian schools use a method that educates the majority to partial bilingualism. It would certainly be very useful to try to adopt a bilingual education more efficiently, to increase the number of people who can use both languages equally well, especially in frontier regions. When speaking of Croatia, one of those regions is Istria, which has minority schools. Those minority schools have the same plan and curriculum as the majority schools, with the difference of the language taught. The Croatian educational curriculum comes under the weak forms of bilingual education for bilinguals, which means that the same applies to minority schools too, in Istria and in the rest of Croatia. The logical conclusion is that the work plan should be radically changed, that the problem should be thoroughly studied regionally, and therefore go through the teaching hours of various school subjects, the teaching language, and perhaps even the curriculum and school policy to adopt.

This could be a very radical and ambitious change, and, if done correctly could bring benefits to future generations. First of all, an efficient bilingualism brings cultural benefits, cognitive traits, increases employment opportunities and facilitates business trips abroad (Albers and Borgschulte, 2009). However, the major benefit that bilingualism can give to people, and consequently to the Croatian people too, is peace and brotherhood with others, and greater openness to different cultures. A really good knowledge of two or more languages and culture removes hatred, or at least reduces it, and brings serenity to a person, who gets rid of stereotypes.

In conclusion, seeing the benefits that a person can enjoy with a good knowledge of two or more languages, I would like to point out that it is important to adopt a bilingual approach to education, that is well structured and well-executed and that meets the needs of the area where it is put into practice, but above all that it is well accepted by all the surrounding society, or at least by most, so it can be really effective. Bilingualism is the present, but also, and most of all, the future of our world society.

\section{Bibliography}

A.V.V. (1965), Dizionario della lingua italiana; Aldo Garzanti Editore; Milano.

Albers, K.; Borgschulte, U. (2009), Bilingualism in the family; http://egora.uni-muenster. de/ew/persoenlich/scheerer/.../12-in-the-famliy.doc.

Baker, C. (2007), Foundation of bilingual education and bilingualism; Multilingual Matters LTD; Bristol.

Bialystok, E. (2006), Bilingualism in development: language, literacy \& cognition; Cambridge University Press; Cambridge.

Deshays, E. (2003), Come favorire il bilinguismo dei bambini; Red edizioni, Novara.

Titone, R. (1993), Bilinguismo precoce ed educazione bilingue; Armando Editore, Roma. 
Metodički obzori 6(2011)3

Stručni rad

UDK: 37-053.5:81'246.2/.3

Primljeno: 23. 11. 2010.

\section{DVOJEZIČNI ODGOJ}

Andrea Močinić, diplomirani učitelj Talijanska osnovna škola Buje (Hrvatska) e-mail: amocinic@gmail.com

\section{Sažetak}

Dvojezičnost, tj. sposobnost poznavanja dvaju jezika, je jako zanimljiva, ali i veoma opširna tema. To nas navodi na činjenicu da je i dvojezični odgoj vrlo kompleksna tema u sklopu koje možemo naći mnogobrojne i praktične pedagoške teorije te školske metodologije. U ovom članku nalaze se istraživanja nekoliko uglednih pedagoga, psihologa, lingvista (Baker, 2007; Bialystock, 2006; Titone, 1993; Deshays, 2003), te se uspoređuju njihova različita mišljenja. Autor ovoga članka se prije svega bavi vrstama dvojezičnog odgoja, te ih međusobno uspoređuje, nalazi njihove dobre i loše strane, i na kraju razmatra najučinkovitije edukativne tipologije. U zaključku pokušava se pronaći vrsta dvojezičnog odgoja koja bi najviše odgovarala istarskoj regiji, u kojoj je dvojezičnost prisutna već stoljećima.

Ključne riječi: bilingvizam, multikulturalizam, interkulturalizam, obrazovanje, škola

\section{L'EDUCAZIONE BILINGUE}

\section{Rias s u n to}

Il bilinguismo, e cioè la capacità di una persona di conoscere e saper usare due lingue, è un tema molto interessante ma altrettanto complesso. Ne consegue che parlando di educazione al bilinguismo si possa trovare una moltitudine di teorie pedagogiche e metodologie scolastiche da mettere in pratica. In questo articolo vengono prese in considerazione le ricerche di alcuni studiosi conosciuti nel mondo della pedagogia, della psicologia, della linguistica (Baker, 2007; Bialystock, 2006; Titone, 1993; Deshays, 2003), e confrontate le idee pervenute dai loro lavori. L'articolo tratta in maggior parte i tipi di educazione bilingue, paragonati tra di loro, analizzando i pregi e i difetti e discutendo, infine, le tipologie educative migliori. In conclusione si riflette pure sul tipo di educazione bilingue più adatto al territorio dell'Istria, regione che è da secoli direttamente interessata al tema del bilinguismo.

Parole chiave: Bilinguismo, multiculturalismo, interculturalismo, educazione, scuola 